\title{
TINJAUAN YURIDIS TENTANG PARALEGAL DALAM PEMBERIAN BANTUAN HUKUM
}

\author{
Afif Khalid; Dadin Eka Saputra \\ Fakultas Hukum Universitas Islam Kalimantan MAB \\ Jalan Adhyaksa No. 2 Kayutangi Banjarmasin Kalimantan Selatan \\ E-mail: afifkhalid@uniska.ac.id; delawfirm30@gmail.com
}

\begin{abstract}
This research will discuss a juridical review of paralegals in the provision of legal assistance where there is an overlap of authority between Advocates and paralegals who through Regulation of the Minister of Law and Human Rights Permenkumham Number 01 Year 2018 are authorized to obtain proceedings both in non-litigation and litigation. The short-term goal expected from this research is to provide a critical analysis of paralegals in the provision of legal assistance in a justice system in Indonesia. The long-term goal of this research can be an appropriate and effective framework in solving problems regarding the provision of legal assistance as efforts to provide legal protection for justice seekers. This research uses a normative juridical research method. This normative legal research was conducted in a qualitative descriptive, normative descriptive means that the material or legal materials are collected, sorted and subsequently studied and analyzed for content, so that it can know the level of synchronization, the feasibility of norms, and the submission of new normative ideas.
\end{abstract}

Keynote: Paralegals, Advocate, Legal Aid, Justice.

\begin{abstract}
Abstrak
Penelitian ini akan membahas tentang tinjauan yuridis tentang paralegal dalam pemberian bantuan hukum dimana terdapat tumpang tindih kewenangan antara Advokat dengan paralegal yang melalui Permenkumham Nomor 01 Tahun 2018 diberikan wewenang untuk dapat beracara baik secara non litigasi maupun litigasi. Tujuan jangka pendek yang diharapkan dari penelitian ini adalah untuk memberikan analisa kritis terhadap paralegal dalam pemberian bantuan hukum dalam sebuah sistem peradilan di Indonesia. Tujuan jangka panjang dari penelitian ini dapat menjadi kerangka kerja yang tepat dan efektif dalam menyelesaikan permasalahan tentang pemberian bantuan hukum sebagai upaya-upaya pemberian perlindungan hukum para pencari keadilan. Penelitian ini menggunakan metode penelitian yuridis normatif. Penelitian hukum normatif ini dilakukan secara deskriptif kualitatif, yaitu materi atau bahanbahan hukum tersebut dikumpulkan, dipilah-pilah untuk selanjutnya dipelajari dan dianalisis muatannya, sehingga dapat diketahui taraf sinkronisasinya, kelayakan norma, dan pengajuan gagasan-gagasan normatif baru.
\end{abstract}

Kata Kunci: Paralegal, Advokat, Pemberian Bantuan Hukum, Peradilan. 


\section{LATAR BELAKANG MASALAH}

Negara hukum sebagai suatu istilah dalam perbendaharaan Bahasa Indonesia merupakan terjemahan dari rechtsstaat maupun rule of law, ketiga istilah tersebut memiliki arah yang sama, yaitu mencegah kekuasaan absolut demi pengakuan dan perlindungan hak asasi. ${ }^{1}$ Dalam Kamus Bahasa Indonesia, istilah negara hukum diartikan sebagai negara yang menjadikan hukum sebagai kekuasaan tertinggi. ${ }^{2}$ Lebih lanjut dijelaskan bahwa negara hukum terdiri dari negara hukum formal dan negara hukum material. Negara hukum formal adalah negara yang segala tindakannya didasarkan hanya atas hukum yang tertulis, yang secara formal tercantum dalam peraturan perundang-undangan, sedangkan negara hukum material adalah negara yang tidak hanya mendasarkan segala tindakannya pada peraturan perundang-undangan, tetapi juga menyelenggarakan kesejahteraan umum. ${ }^{3}$

Undang-Undang Nomor 16 Tahun

2011 tentang Bantuan Hukum telah didefinisikan sebagai lembaga bantuan hukum atau organisasi kemasyarakatan

${ }^{1}$ Azhary, 1995, Negara Hukum IndonesiaAnalisis Yuridis Normatif Tentang Unsur-unsurnya, Cet. Pertama, Jakarta: UI Press, hlm. 30.

2 Pusat Pembinaan dan Pengembangan Bahasa, 1996, Kamus Besar Bahasa Indonesia, Edisi yang bertugas memberikan layanan bantuan hukum berdasarkan undang-undang. Kemudian, pemberi bantuan hukum diberikan kewenangan pula untuk merekrut advokat, paralegal, dosen, dan mahasiswa fakultas hukum. Selain berdasar pada Undang-Undang Nomor 16 Tahun 2011tentang Bantuan Hukum, telah diatur pula konsep tentang legitimasi untuk dapat beracara baik didalam maupun diluar persidangan yaitu melalui Undang-Undang Nomor 18 Tahun 2003 tentang Advokat. Melalui Undang-Undang Nomor 18 Tahun 2003 tentang Advokat maka seorang Advokat dalam menjalankan profesinya dalam memberikan bantuan hukum dan beracara dalam persidangan sebuah perkara memang telah mempunyai kewenangan yang mana hal tersebut telah diberikan secara langsung oleh Undang-Undang Nomor 18 Tahun 2003 tentang Advokat. Hal ini tentu saja berbeda dengan posisi paralegal, dosen, maupun mahasiswa fakultas hukum yang hanya mendasarkan pada ketentuan Undang-Undang Nomor 16 Tahun 2011 tentang Bantuan Hukum.

Pada tanggal 17 Januari 2018 Menteri hukum dan HAM R.I Yasona

Kedua, Cet. Kedelapan, Jakarta: Balai Pustaka, hlm. 685.

$$
3 \text { Ibid. }
$$


Hamonangan Laoly telah menandatangani Permenkumham Nomor 1 Tahun 2018 yang mengatur tentang paralegal, kemudian diundangkan pada tanggal 26 Januari 2018 oleh Direktur Jenderal Peraturan Perundang-undangan Widodo Ekatjahyana, dimana Permenkumham ini dibentuk untuk melaksanakan Undang-Undang Nomor 16 Tahun 2011 tentang Bantuan Hukum.

Permenkumham tentang paralegal ini mengatur mengenai kedudukan paralegal dalam pemberian bantuan hukum gratis bagi orang miskin. Paralegal dapat memberikan bantuan hukum baik itu secara litigasi dan non litigasi. Mulai dari penyidikan, penuntutan, dan persidangan.

Kalangan advokat yang dipimpin oleh Bireven Aruan, S.H., M.H pada tanggal 06 April 2018 mengajukan permohonan uji materiil terhadap Permenkumham Nomor 1 Tahun 2018. Selain Bireven Aruan, S.H., M.H., ada beberapa advokat lainnya yang bertindak sebagai pemohon diantaranya, Johan Imanuel, S.H., Irwan Gustav Lalegit, S.H., Martha Dinata, S.H., Abdul Jabbar, S.H.I., Ika Arini Batubara, S.H., Indra Rusmi S.H., Abdul Salam, S.H., Ade Anggraini, S.H., Arnol Sinaga, S.H., Alvin Maringin, S.H., Teuku Muttaqin, S.H., Endin, S.H., dan Fista Sambuari, S.H.
Dengan diterimanya sebagian permohonan Uji Materiil ini maka eksistensi paralegal sebagaimana yang diatur dalam Permenkumham Nomor 01 Tahun 2018 menjadi tidak lagi dapat memberikan pendampingan terhadap para pencari keadilan baik secara non litigasi maupun secara litigasi.

\section{RUMUSAN MASALAH}

Berdasarkan latar belakang masalah sebagimana di paparkan sebelumnya, rumusan masalah dalam penelitian ini adalah sebagi berikut:

1. Apa dampak implikatif pasca dikabulkannya permohonan pembatalan Peraturan Menteri Hukum dan HAM Nomor 1 Tahun 2018 oleh Mahkamah Agung?

2. Bagaimana pengaturan ideal konsep pemberian bantuan hukum dalam sistem peradilan di Indonesia guna melindungi hak-hak para pencari keadilan?

\section{METODE PENELITIAN}

Penelitian ini dilakukan dengan jenis penelitian hukum normatif berupa penelitian kepustakaan yang menggunakan 3 (tiga) bahan hukum yaitu bahan hukum primer, bahan hukum sekunder dan bahan hukum tersier. Penelitian hukum ini 
menitikberatkan pada studi kepustakaan yang berarti akan lebih banyak menelaah dan mengkaji aturan-aturan hukum yang ada dan berlaku. Dalam penelitian ini memerlukan bahan-bahan hukum hukum karena akan berfungsi untuk melengkapi dan menunjang bahan hukum dalam penelitian kepustakaan (library research).

Menurut Soerjono Soekanto yang dimaksud dengan metode penelitian hukum normatif atau metode penelitian hukum kepustakaan adalah metode atau cara yang dipergunakan di dalam penelitian hukum yang dilakukan dengan cara meneliti bahan pustaka yang ada. ${ }^{4}$ Dalam hal ini mengenai penegakan hukum dalam penyelanggaraan Pemilihan Kepala Daerah. Pendekatan yang digunakan dalam penelitian ini adalah statute approach atau pendekatan perundang-undangan sebab menggunakan pendekatan legislasi dan regulasi. ${ }^{5}$

\section{PEMBAHASAN}

Dampak Implikatif Pasca

Dikabulkannya Permohonan

Pembatalan Peraturan Menteri Hukum

Dan HAM Nomor 1 Tahun 2018 Oleh Mahkamah Agung

4 Soerjono Soekanto dan Sri Mamudji, 2009, Penelitian Hukum Normatif Suatu Tinjauan Singkat, Jakarta: PT. Raja Grafindo Persada, Cetakan ke-11, hlm.13-14.
Arti dan tujuan program bantuan hukum berbeda-beda dan berubah-ubah, bukan saja dari suatu negara ke negara lainnya, melainkan juga dari satu zaman ke zaman lainnya, suatu penelitian yang mendalam tentang sejarah pertumbuhan program bantuan hukum telah dilakukan oleh Dr. Mauro Cappeleti, dari penelitian tersebut ternyata program bantuan hukum kepada masyarakat miskin telah dimulai sejak zaman Romawi. Dari penelitian tersebut, dinyatakan bahwa tiap zaman arti dan tujuan pemberian bantuan hukum kepada masyarakat yang tidak mampu erat hubungannya dengan nilai-nilai moral, pandangan politik dan falsafah hukum yang berlaku. $^{6}$

Pengertian bantuan hukum yang lingkup kegiatannya cukup luas ditetapkan dalam Lokakarya Bantuan Hukum Tingkat Nasional tahun 1978 yang menyatakan bahwa bantuan hukum yang diberikan kepada golongan tidak mampu (miskin) baik secara perorangan maupun kepada kelompok-kelompok masyarakat tidak mampu secara kolektif. Lingkup kegiatan meliputi pembelaan, perwakilan baik di luar

\footnotetext{
${ }^{5}$ Ibid. hlm.97.

${ }^{6}$ Adnan Buyung Nasution, 1988, Bantuan Hukum di Indonesia, LP3ES, Jakarta, hlm.4.
} 
maupun di dalam pengadilan, pendidikan, penelitian dan penyebaran gagasan.

Arti dan tujuan program bantuan hukum di Indonesia adalah sebagimana tercantum dalam anggaran dasar Lembaga Bantuan Hukum (LBH) karena Lembaga Bantuan Hukum (LBH) mempunyai tujuan dan ruang lingkup kegiatan yang lebih luas dan lebih jelas arahannya sebagai berikut:

a. Memberikan pelayanan hukum kepada masyarakat yang membutuhkannya;

b. Membidik masyarakat dengan tujuan membutuhkan dan membina kesadaran akan hak-hak sebagai subjek hukum;

c. Mengadakan pembaharuan hukum dan perbaikan pelaksanaan hukum disegala bidang.

Pasal 1 ayat (1) Undang-Undang Nomor 16 Tahun 2011 Tentang Bantuan Hukum menyatakan bahwa bantuan hukum adalah jasa hukum yang diberikan oleh Pemberi Bantuan Hukum secara cumacuma kepada Penerima Bantuan Hukum. Pasal 9 huruf a menyatakan bahwa pemberi bantuan hukum berhak merekrut advokat, paralegal, dosen, mahasiswa fakultas hukum.

Dijelaskan dalam Undang-Undang Tentang Bantuan Hukum Nomor 16 Tahun
2011 Pemberi Bantuan Hukum adalah lembaga bantuan hukum atau organisasi kemasyarakatan yang memberi layanan bantuan hukum. Memang tidak semua Lembaga Bantuan Hukum atau Organisasi Kemasyarakatan dalam konteks aturan ini bisa menjadi Pemberi Bantuan Hukum. Dimana di dalam Pasal 8 ayat (1) dan ayat (2) disebutkan:

(1) Pelaksanaan Bantuan Hukum dilakukan oleh Pemberi Bantuan Hukum yang telah memenuhi syarat berdasarkan Undang-Undang ini.

(2) Syarat-syarat Pemberi Bantuan Hukum sebagaimana dimaksud pada ayat (1) meliputi:

a. berbadan hukum;

b. terakreditasi berdasarkan Undang-Undang ini;

c. memiliki kantor atau sekretariat yang tetap;

d. memiliki pengurus; dan

e. memiliki program Bantuan Hukum.

Hal diatas sangatlah berbeda pengertiannya dengan definisi Bantuan Hukum dalam Undang-Undang Advokat. Pasal 22 Undang-Undang Advokat berbunyi: "Advokat wajib memberikan bantuan hukum secara cuma-cuma kepada pencari keadilan yang tidak mampu". 
Sehingga yang dititik beratkan dalam Undang-Undang Bantuan Hukum adalah aspek kewajiban dan tanggung jawab negara melalui Kementerian terkait (Kemenkumham), namun dalam tekhnis pelaksanaannya diserahkan kepada masyarakat melalui Lembaga Bantuan Hukum atau Organisasi Kemasyarakatan yang telah memenuhi syarat-syarat dalam UndangUndang atau Peraturan-Peraturan dibawahnya. Sedangkan dalam UndangUndang Advokat yang dititik beratkan adalah kewajiban seorang Advokat sebagai Officium Nobille.

Paralegal sering dikenal sebagai pendamping, yang menjalankan aktifitas hukum sebagaimana dilakukan oleh pengacara yaitu memberikan bantuan hukum baik melalui jalur pengadilan maupun di luar jalur pengadilan, sebatas kemampuan yang dimiliki oleh orang yang menjalankan aktifitas keparalegalan. ${ }^{7}$

Tugas paralegal yang dapat bersidang di pengadilan secara litigasi dan non litigasi tidak hanya ada di Permenkumham Nomor 1 Tahun 2018, tetapi juga diatur dalam Undang-Undang Bantuan Hukum dan Pasal 1 ayat (3), 3, 4, 5 dan Pasal 16 Peraturan Pemerintah No. 42

\footnotetext{
${ }^{7}$ Eko Roesanto, Perkembangan Paralegal
} Untuk Masyarakat Miskin dan Kelompok Marginal
Tahun 2013 tentang Syarat dan Tata Cara Pemberian Bantuan Hukum dan Penyaluran Dana Bantuan Hukum.

Ketentuan Pasal 1 ayat (3) UndangUndang Nomor 16 Tahun 2011 tentang Bantuan Hukum menyatakan bahwa:

"Pemberi Bantuan Hukum adalah lembaga bantuan hukum atau organisasi kemasyarakatan yang memberi layanan Bantuan Hukum berdasarkan UndangUndang ini”.

Ketentuan Pasal 3 Undang-Undang Nomor 16 Tahun 2011 tentang Bantuan Hukum menyatakan bahwa:

"Penyelenggaraan Bantuan Hukum bertujuan untuk:

a. Menjamin dan memenuhi hak bagi Penerima Bantuan Hukum untuk mendapatkan akses keadilan;

b. Mewujudkan hak konstitusional segala warga negara sesuai dengan prinsip persamaan kedudukan di dalam hukum";

c. Menjamin kepastian penyelenggaraan Bantuan Hukum dilaksanakan secara merata di seluruh wilayah Negara Republik Indonesia; dan

d. Mewujudkan peradilan yang efektif, efisien, dan dapat dipertanggungjawabkan.

Ketentuan Pasal 4 Undang-Undang Nomor 16 Tahun 2011 tentang Bantuan Hukum menyatakan bahwa:

(1) Bantuan Hukum diberikan kepada Penerima Bantuan Hukum yang menghadapi masalah hukum. 11 Mei 2019, Pukul 14.04 WITA. 
(2) Bantuan Hukum sebagaimana dimaksud pada ayat (1) meliputi masalah hukum keperdataan, pidana, dan tata usaha negara baik litigasi maupun nonlitigasi.

(3) Bantuan Hukum sebagaimana dimaksud pada ayat (1) meliputi menjalankan kuasa, mendampingi, mewakili, membela, dan/atau melakukan tindakan hukum lain untuk kepentingan hukum Penerima Bantuan Hukum.

Ketentuan Pasal 5 Undang-Undang

Nomor 16 Tahun 2011 tentang

Bantuan Hukum menyatakan bahwa:

(1) Penerima Bantuan Hukum sebagaimana dimaksud dalam Pasal 4 ayat (1) meliputi setiap orang atau kelompok orang miskin yang tidak dapat memenuhi hak dasar secara layak dan mandiri.

(2) Hak dasar sebagaimana dimaksud pada ayat (1) meliputi hak atas pangan, sandang, layanan kesehatan, layanan pendidikan, pekerjaan dan berusaha, dan/atau perumahan.

Ketentuan Pasal 16 Peraturan

Pemerintah No. 42 Tahun 2013 tentang

Syarat dan Tata Cara Pemberian Bantuan

Hukum dan Penyaluran Dana Bantuan

Hukum yang menyatakan bahwa:

(1) Pemberian Bantuan Hukum secara Nonlitigasi dapat dilakukan oleh Advokat, paralegal, dosen, dan mahasiswa fakultas hukum dalam lingkup Pemberi Bantuan Hukum yang telah lulus Verifikasi dan Akreditasi.

(2) Pemberian Bantuan Hukum secara Nonlitigasi meliputi kegiatan:
a. penyuluhan hukum;

b. konsultasi hukum; c. investigasi perkara, baik secara elektronik maupun nonelektronik;

d. penelitian hukum;

e. mediasi;

f. negosiasi;

g. pemberdayaan masyarakat;

h. pendampingan di luar pengadilan; dan/atau

i. drafting dokumen hukum.

Mahkamah Agung membatalkan Pasal 11 dan Pasal 12 merupakan 'jantung' dari Permenkumhan Nomor 1 Tahun 2018, sehingga secara otomatis pasal-pasal lain serta merta tidak berlaku lagi. Secara tidak langsung pasal yang terdapat dalam Undang-Undang Bantuan Hukum dan Peraturan Pemerintah Nomor 42 Tahun 2013 itu tidak bisa dilaksanakan akibat adanya putusan Mahkamah Agung ini. Mulai dari Pasal 9 dan seterusnya UndangUndang Bantuan Hukum serta Pasal 3, 4, 5, dan Pasal 16 Peraturan Pemerintah No. 42 Tahun 2013.

Sehingga pula pendampingan tentang perkara Pro Bono [Cuma-Cuma] dikhawatirkan akan tidak berjalan efektif mengingat bahwa ada bagian tugas dan tanggung jawab negara untuk membantu para pencari keadilan yang tidak mampu.

Pengaturan Ideal Konsep Pemberian Bantuan Hukum Dalam Sistem Peradilan Di Indonesia Guna 


\section{Melindungi Hak-Hak Para Pencari Keadilan}

Mahkamah Agung telah memutuskan sebagian isi Peraturan Menteri Hukum dan HAM (Permenkumham) Nomor 1 Tahun 2018 tentang Paralegal dalam Pemberian Bantuan Hukum bertentangan dengan peraturan perundang-undangan yang lebih tinggi. Majelis hakim agung membatalkan Pasal 11 dan Pasal 12 Peraturan Menteri itu karena dianggap bertentangan dengan Undang-Undang Nomor 18 Tahun 2003 tentang Advokat.

Majelis hakim agung menyatakan hanya advokat yang telah disumpah di Pengadilan Tinggi yang dapat beracara dalam proses pemeriksaan di pengadilan. Paralegal hanya "membantu" tugas advokat. Pada dasarnya tujuan dikeluarkannya Ketentuan Pasal 11 dan 12 Permenkumham memberikan ruang dan kewenangan kepada paralegal untuk dapat beracara di persidangan. Majelis menafsirkan ketentuan tersebut paralegal menjalankan sendiri proses pemeriksaan di persidangan, tanpa didampingi advokat. Inilah yang dinilai majelis bertentangan dengan Pasal 4 juncto Pasal 31 UndangUndang Nomor 18 Tahun 2003 tentang Advokat.

Akan tetapi yang menjadi permasalahan sekarang adalah apabila kita merujuk kepada asas lex superior de rogat legi inferiori dimana ketentuan asas ini seharusnya dapat mencakup nilai-nilai dan makna falsafah sebuah peratutan perundnag-undangan secara komprehensif, sehingga tidak hanya merujuk kepada ketentuan Undang-Undang Nomor 18 Tahun 2003 tentang Advokat saja akan tetapi harus merujuk kepada ketentuan perundang-undangan yang lain seperti Undang-Undang Nomor 16 Tahun 2011 tentang Bantuan Hukum.

Asas hukum lex superior derogate legi inferiori bermakna peraturan perundangundangan yang lebih tinggi kedudukannya mengesampingkan peraturan yang lebih rendah. Sebaliknya, peraturan yang lebih rendah harus merujuk dan mendasarkan diri pada peraturan yang lebih tinggi. Putusan Mahkamah Agung mengunakan asas itu untuk menyatakan bahwa Permenkumham bertentangan dengan Undang-Undang Nomor 18 Tahun 2003 tentang Advokat. Tetapi, majelis tidak mempertimbangkan asas ini untuk ketentuan yang bersifat khusus. Pembentuk Undang-Undang menerbitkan Permenkumham dengan maksud khusus ataulex specialis dalam konteks pemberian bantuan hukum.

Selain itu, putusan Mahkamah dinilai tidak mempertimbangkan peran paralegal yang secara de facto telah berkontribusi 
secara nyata dalam pemberian bantuan hukum. Pertimbangan hakim yang hanya merujuk konsep paralegal konvensional sebagai konsep tunggal untuk memutus perkara HUM ini dinilai telah mengesampingkan fakta tentang peran paralegal komunitas yang selama ini sudah berjalan dan menjadi kebutuhan masyarakat miskin dan termarjinalkan.

Kementerian Hukum dan HAM (Kemenkumham) perlu memperjelas definisi, fungsi dan instrumen mengenai paralegal agar tidak menimbulkan multitafsir dalam implementasinya. Tidak hanya merevisi Permenkumham tersebut, tetapi juga merevisi Undang-Undang Bantuan Hukum untuk memperjelas mengenai definisi dan fungsi paralegal.

Perlu adanya koordinasi antara Kementerian Hukum dan HAM beserta organisasi Advokat guna menyeleraskan dan menyamakan persepsi maupun visi terkait dengan paralegal. Dimana hal tersebut telah diatur dalam UU Nomor 18 Tahun 2003, Undang-Undang Bantuan Hukum serta PP No. 42 Tahun 2013 tentang Syarat dan Tata Cara Pemberian Bantuan Hukum dan Penyaluran Dana Bantuan Hukum. Agar supaya dapat memberikan kepastian hukum dan perlindungan hukum bagi para pencari keadilan yang kurang mampu.
Selain itu adalah merevisi Permenkumham tentang Paralegal. Dimana Pemerintah bersama pihak yang berkepentingan melakukan revisi terhadap Permenkumham. Revisi ini perlu mengakomodasi model-model paralegal yang telah berkembang di masyarakat, baik paralegal konvensional maupun paralegal komunitas.

\section{KESIMPULAN}

Keberadaan Paralegal di masyarakat sesungguhnya merupakan respon atas: (1) situasi dan kondisi masyarakat, terutama kelompok miskin dan marginal, yang berada pada posisi yang lemah untuk memperoleh akses keadilan; dan (2) kelemahan sistem hukum dalam menjalankan fungsi utamanya sebagai pelayan masyarakat pencari keadilan.

Tugas paralegal yang dapat bersidang di pengadilan secara litigasi dan non litigasi tidak hanya ada di Permenkumham No. 1 Tahun 2018, tetapi juga diatur dalam Undang-Undang Bantuan Hukum dan Pasal 1 ayat (3), 3, 4, 5 dan Pasal 16 PP No. 42 Tahun 2013 tentang Syarat dan Tata Cara Pemberian Bantuan Hukum dan Penyaluran Dana Bantuan Hukum.

Mahkamah Agung membatalkan Pasal 11 dan Pasal 12 merupakan 'jantung' 
dari Permenkumhan No. 1 Tahun 2018, sehingga secara otomatis pasal-pasal lain serta merta tidak berlaku lagi. Secara tidak langsung pasal yang terdapat dalam Undang-Undang Bantuan Hukum dan Peraturan Pemerintah No. 42 Tahun 2013 itu tidak bisa dilaksanakan akibat adanya putusan Mahkamah Agung ini. Mulai dari Pasal 9 dan seterusnya Undang-Undang Bantuan Hukum serta Pasal 3, 4, 5, dan Pasal 16 Peraturan Pemerintah No. 42 Tahun 2013.

Perlu adanya koordinasi antara Kementerian Hukum dan HAM beserta organisasi Advokat guna menyeleraskan dan menyamakan persepsi maupun visi terkait dengan paralegal. Dimana hal tersebut telah diatur dalam UU Nomor 18 Tahun 2003, Undang-Undang Bantuan Hukum serta PP No. 42 Tahun 2013 tentang Syarat dan Tata Cara Pemberian Bantuan Hukum dan Penyaluran Dana Bantuan Hukum. Agar supaya dapat memberikan kepastian hukum dan perlindungan hukum bagi para pencari keadilan yang kurang mampu.

Selain itu adalah merevisi Permenkumham tentang Paralegal. Dimana Pemerintah bersama pihak yang berkepentingan melakukan revisi terhadap Permenkumham. Revisi ini perlu mengakomodasi model-model paralegal yang telah berkembang di masyarakat, baik paralegal konvensional maupun paralegal komunitas.

\section{DAFTAR PUSTAKA}

\section{Buku}

Azhary, 1995, Negara Hukum IndonesiaAnalisis Yuridis Normatif Tentang Unsur-unsurnya, Cet. Pertama, Jakarta: UI Press.

Nasution, Adnan Buyung Nasution, 1988, Bantuan Hukum di Indonesia, LP3ES, Jakarta.

Pusat Pembinaan dan Pengembangan Bahasa, 1996, Kamus Besar Bahasa Indonesia, Edisi Kedua, Cet. Kedelapan, Jakarta: Balai Pustaka.

Roesanto, Eko, 2019, Perkembangan Paralegal Untuk Masyarakat Miskin dan Kelompok Marginal di Indonesia, http://www.kompasiana.com.

Soekanto, Soerjono dan Sri Mamudji, 2009, Penelitian Hukum Normatif Suatu Tinjauan Singkat, Jakarta: PT. Raja Grafindo Persada, Cetakan ke-11.

\section{Peraturan Perundang-undangan}

Undang-Undang Dasar NRI Tahun 1945 Dalam Satu Naskah, 2006, Jakarta: PT. Citra Umbara.

Undang-Undang Nomor 16 Tahun 2011 tentang Bantuan Hukum.

Undang-Undang Nomor 18 Tahun 2003 tentang Advokat. 
